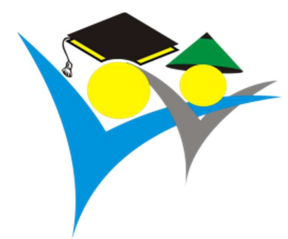

\title{
Strategi Pengendalian Invasi Hama Baru Ulat Grayak Jagung, Spodoptera frugiperda, Di Daerah Sentra Produksi Kabupaten Lombok Barat
}

\author{
Bambang Supeno $^{1 *}$, Tarmizi $^{1}$, Hery Haryanto ${ }^{1}$, Ni Made Laksmi Ernawati ${ }^{1}$, M. Taufik Fauzi ${ }^{1}$ \\ ${ }^{\text {I}}$ (Program Studi Agroekoteknologi, Fakultas Pertanian Universitas Mataram, Mataram - Indonesia.
}

Article history

Received: 10 Desember 2021

Revised: 18 Desember 2021

Accepted: 20 Desember 2021

*Corresponding Author:

Bambang Supeno,

Program Studi Agroekoteknologi, Fakultas Pertanian Universitas

Mataram, Mataram - Indonesia.

Email: bsupeno59@unram.ac.id
Abstract: Corn plant in growing season last year up to now threatened by new pest from America continent namely Fall Armyworm (FAW). Armyworm Spodoptera frugiperda reported its spread all over Indonesia region including NTB province. This pest arrival as new threat in corn self-sufficiency in NTB, as reported corn crop failure by most farmers in Lombok island. Emergency response had been done by pesticide eradication but there was no satisfication result. One of the alternatives offered was by effective and environmentally friendly control strategy. There were two main service activities namely field direct practical training and discussion, and making of demonstration plot on June till October 2020. Demonstration plot was conducted in the one of Rahayu farmer group member's field on Jatisela village, Gunungsari district. The results and conclusions of this service activities are as follows: (a) Farmers participating in the service activities are increasingly understanding the strategy of controlling new invasion pests of corn caterpillars using refusia plants and monitoring. (b) Farmers are increasingly confident that method could reduce caterpillar attacks by up to $80 \%$ (c). That method also was showed savings in the cost of purchasing pesticides up to $100 \%$. (d) Farmers are increasingly understanding that there is a comparison between demonstration plot results and farmers' methods, namely the quality and yield of demonstration plot shelled corn is better than local farmers' control techniques.

Keywords: strategy; control; new pest; spodoptera frugiperda

Abstrak: Tanaman jagung pada musim tanam tahun lalu hingga sekarang terancam oleh datangnya Hama Baru dari benua Amerika, yaitu hama ulat grayak jagung ( fall armyworm/FAW). Hama ulat grayak jagung, Spodoptera frugiperda telah menyebar di seluruh wilayah Indonesia, termasuk Provinsi NTB. Kedatangan hama ini merupakan acaman baru dalam swasembada jagung di NTB, seperti telah dilaporkan kegagalan panen jagung oleh sebagian besar petani di pulau Lombok. Penanggulangan darurat telah dilakukan dengan melakukan eradikasi memakai pestisida namun belum membuahkan hasil yang memuaskan. Salah satu alternatif yang ditawarkan ke petani adalah melakukan strategis pengendalian yang efektif dan ramah lingkungan. Kegiatan pengabdian meliputi dua kegiatan pokok yaitu Pelatihan praktek langsung lapangan dan diskusi dan pembuatan demplot tanaman jagung pada bulan Juni-Oktober 2020. Demplot dilaksanakan di sawah milik salah satu anggota Kelompok Tani "Rahayu" di desa Jatisela, Kecamatan Gunungsari. Hasil kegiatan pengabdian seperti berikut: (a) Petani peserta kegiatan pengabdian semakin memahami strategi teknik pengendalian hama invasi baru ulat gerayak jagung dengan menggunakan tanaman refusia dan monitoring. (b) Petani semakin mengerti bahwa dengan teknik pengendalian tanam refusia dan monitoring dapat menekan serangan hama ulat grayak hingga $80 \%$ (c) dan penghematan biaya pembelian pestisida hingga $100 \%$. (d) Petani semakin mengerti dengan adanya perbandingan antara hasil Demplot dan cara petani, yaitu kualitas dan hasil jagung pipil demplot lebih bagus daripada teknik pengendalian cara petani setempat.

Kata kunci: strategi; pengendalian; hama-baru; spodoptera-frugiperda 


\section{PENDAHULUAN}

Jagung (Zea mays) merupakan makanan pokok masyarakat Indonesia setelah beras, sehingga keberadaan jagung sangat dibutuhkan dalam rangka ketahanan pangan di Indonesia. Akil dan Dahlan (2003) menyatakan bahwa jagung merupakan penyumbang terbesar ke-2 setelah padi dalam subsektor tanaman pangan. Sumbangan jagung terhadap Produk Domestik Bruto (PDB) terus meningkat setiap tahun, sekalipun pada saat krisis ekonomi. Di Indonesia untuk memenuhi kebutuhan konsumsi domestik masih mengimpor jagung dari luar. Dalam rangka peningkatan dan swasembada pangan pemerintah dalam tiga tahun ini telah melakukan program PAJALE (Padi Jagung Kedelai). Program ini telah berhasil dan NTB merupakan salah satu sentra Produksi Nasional. Produksi jagung di Nusa Tenggara Barat tahun pada tahun 2018 sebesar 63,88 ton pipilan kering (BPS NTB 2019). Produksi dan swasembada jagung tersebut terancam gagal akibat ancaman hama invasi baru Ulat Grayak Jagung

Hama ulat grayak jagung Spodoptera frugiperda J.E. Smith merupakan serangga invasif baru di Indonesia. Hama ini berasal dari Amerika Tengah menyebar ke Afrika tahun 2016, India 2017, dan Indonesia pada tahun 2019. (CABI, 2019, Sharanabasappa et al., 2019, Kementan 2019). Di Indonesia serangan hama ini, pertama kali muncul pada musim tanam jagung di bulan April - Mei 2019 di beberapa sentra produksi Jagung di pulau Sumatra. Hama ini sudah cukup meresahkan bagi petani jagung di Lampung, Sumatera Barat, Aceh. Riau, Jambi, Bengkulu, Sumatera Selatan, Lampung, dan pulau Jawa seperti di Banten, Bandung, Sumedang, Garut, jawa Tengah, Jawa Timur serta NTB (Maharani et al., 2019, BPTP NTB, 2019, Kementan 2019). Karena telah banyak yang tanamannya hancur dan gagal panen jagung karena serangan Spodoptera frugiperda ini (Supeno et al., 2020). Hal ini secara menyeluruh penulis temukan di Provinsi NTB, khususnya di Pulau Lombok telah menyebar ke seluruh Kabupaten dan Kota (Supeno et al., 2021). Bila kondisi ini tidak ditangani secara bijak akan mengancam swasembada jagung, khususnya di NTB yang telah dijadikan sebagai salah satu lumbung jagung Nasional.

Penyebaran hama ini sangat cepat dalam kurun waktu yang tidak lama hampir seluruh Indonesia telah dilaporkan keberadaannya. Kerugian yang dilaporkan menyebabkan kegagalan panen sehingga tanaman jagung terpaksa dijadikan sebagai pakan ternak (Dinas Pertanian NTB 2019). Pengendalian dalam penyebaran hama ini telah dilakukan oleh berbagai Instansi terkait dengan melakukan eradikasi kimiawi dan hasilnya belum memuaskan.

Salah satu solusi yang ditawarkan dalam penangkalan hama baru yang belum diketahui caranya yang tepat adalah tetap menggunakan pestisida yang saat ini banyak dilakukan oleh petani dalam jangka pendek. Namun penggunaan pestisida tersebut harus secara bijak dengan meminimalkan dampak negatif terhadap lingkungan.

Adanya introduksi pengetahuan teknik pengendalian hama secara kimiawi dengan menggunakan pestisida secara bijak tersebut diharapkan petani memperoleh beberapa keuntungan yaitu: (1) mengendalikan hama baru ulat grayak jagung yang efisien, murah dan ramah lingkungan. (2) mempertahankan produksi jagung dan menghasilkan pakan ternak berupa pucuk tanaman jagung. Dengan demikian secara langsung akan tetap mendukung program pemerintah dalam swasembada jagung.

Berdasarkan uraian di atas diharapkan terjadinya suatu kegiatan yang sinergis antara perguruan tinggi, dinas pertanian, dinas perdagangan, pemerintah desa, pengusaha dan masyarakat dalam meningkatkan pendapatan petani melalui swasembada jagung.

\section{METODE}

\section{A. Kelompok Sasaran}

Sasaran dari program ini adalah masyarakat petani jagung yang ada di desa Gunung Sari dengan profil seperti berikut: (1) pekerjaan sebagai petani jagung, (2) berdomisili di desa setempat, (3) memiliki sawah atau lahan garapan tanaman jagung, (4) mempunyai kemauan dan semangat dalam pengendalian hama baru jagung, (5) bersedia mematuhi dan mengikuti petunjuk bimbingan yang dicontohkan, (6) bersedia menyebarluaskan ilmu yang telah diterima kepada para petani lain yang menginginkannya, (7) bertanggung jawab terhadap bantuan dalam peningkatan usaha produksi jagung. 


\section{B. Persiapan}

Persiapan pelaksanaan kegiatan ini adalah berkoordinasi dengan LPPM, Kepala Desa dan Kelompok Tani. Koordinasi dengan Desa dan petani dilakukan saat akan dilakukan pelaksanaan kegiatan. Selain koordinasi persiapan lainnya adalah kesiapan bahan dan alat yang diperlukan dalam melakukan praktek lapangan secara langsung.

\section{Pelaksanaan}

Kegiatan program ini dilakasanakan dengan metode pelatihan yang dilanjutkan dengan kerja praktik di lapangan dan kaji tindak partisipatif aktif (partisipatory action research) sejak persiapan hingga evaluasi.

Kegiatan penyuluhan ini dilakukan pada bulan Juni hingga Oktober 2020 yang meliputi pembuatan demplot, pelatihan, monitoring dilakukan dengan metode (Robert et al., 2008). Pelaksanaan lapangan dengan membuat Demplot percontohan yang melibatkan petani dan mahasiswa.

Mahasiswa dilibatkan sebagai bantuan untuk kegiatan penelitian skripsi yang melakukan penanaman jagung dan aplikasi teknik pengendalian hama. Petani yang dilibatkan adalah anggota kelompok tani jagung yang ada di desa, yaitu Kelompok tani "Rahayu", dengan harapan dapat langsung mengadopsi dan membandingkan teknik yang telah dilakukan.

\section{Program Strategi Pengendalian ulat grayak jagung}

Program ini meliputi: Pelatihan kelompok petani jagung, praktek langsung pembuatan demplot di lapangan, teknik pengendaliannya berupa monitoring hama, penggunaan varietas tahan, dan pengendalian secara mekanik.

Pembuatan Demplot dilakukan di salah satu Dusun di desa Jatisela, Kecamatan Gunungsari. Demplot dilaksanakan di sawah milik salah satu anggota Kelompok Tani "Rahayu" di dusun Ireng, Desa Jatisela. Kegiatan ini meliputi pengolahan tanah, penanaman refusia, monitoring ulat gerayak, jagung, hingga pemanenan.

Penanaman refusia digunakan bunga marigold mengelilingi petak demplot. Refusia disemaikan lebih dahulu sebelum jagung ditanam, yaitu 2 minggu sebelumnya. Penanaman refusia dilakukan bersamaan dengan tanam jagung, yaitu di pematang sawah.

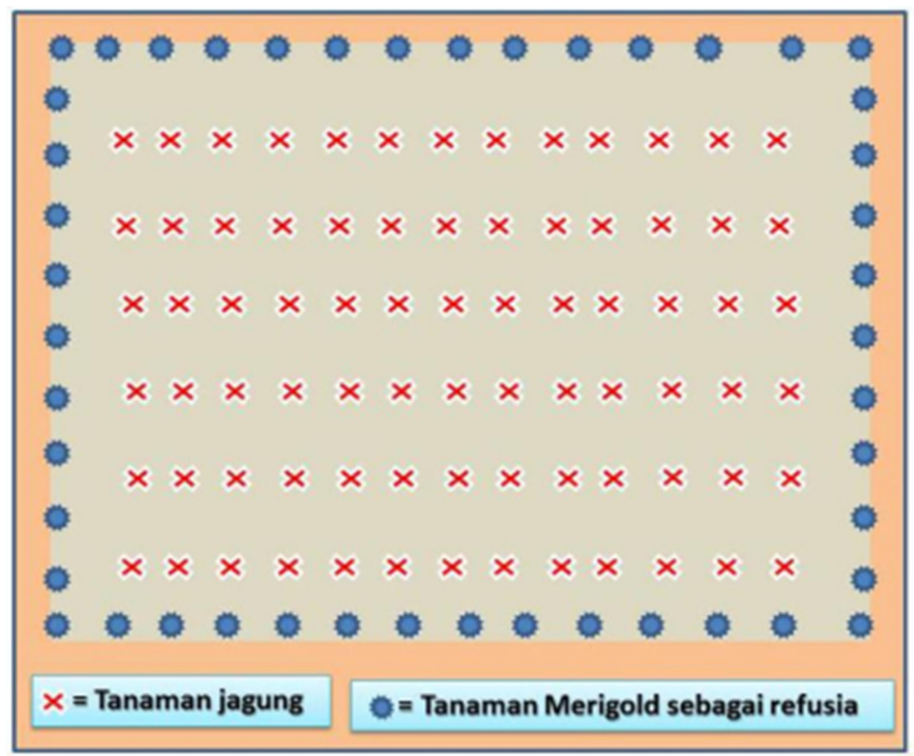

Gambar 1.

Denah Demplot Percobaan 
Monitoring dan pengendalian mekanik dilakukan setiap seminggu sekali selama pertumbuhan tanaman jagung. Monitoring ditujukan untuk mengamati kelompok telur ulat grayak jagung dan mematikannya secara mekanik.

\section{Praktik Lapang}

Praktik lapang ini dilaksanakan oleh petani peserta kegiatan dari anggota Kelompok Tani "Rahayu" dengan arahan tim pelaksana kegiatan pengabdian pada masyarakat. Kegiatan ini ditujukan untuk melakukan monitoring keadaan hama yang ada di demplot. Monitoring dilakukan dengan mengamati setiap pohon khususnya di helai daun dan batang. Sebelum praktik dilakukan dahulu pengenalan bentuk kelompok telur yang diletakkan oleh ngengat betina. Setelah mengenali dilanjutkan praktek langsung pemburuan kelompok telur dan didamping oleh mahasiswa dan tim pengabdian. Pendampingan dilakukan hingga beberapa kali sampai peserta familiar betul apa yang akan dilakukan. Kelompok telur dikoleksi dan dikumpulkan untuk dilanjutkan dibawa ke laboratorium sebagai bahan penelitian. Namun untuk selanjutnya di lahan jagung masing-masing peserta langsung dimusnahkan dengan mengusap hingga jatuh atau hancur.

\section{HASIL DAN PEMBAHASAN}

Pelaksanaan kegiatan pengabdian masyarakat didahului dengan konfirmasi lokasi Desa untuk dijadikan sebagai tempat pelaksanaan pengabdian dengan pertimbangan merupakan salah satu pusat produksi jagung di Lombok Barat. Hasil konfirmasi dan survey pendahuluan ditentukan Desa Jatisela sebagai tempat untuk kegiatan pengabdian pada masyarakat. Pelaksanaan kegiatan ini meliputi pembuatan Demontrasi Plot (Demplot) tanaman jagung dan pelatihan penyuluhan petani peserta pengabdian masyarakat.

\section{Kegiatan Pelatihan Petani}

Pelaksanaan Pelatihan dan Penyuluhan dilakukan di dua kondisi yang berbeda, yaitu pertama pelatihan praktik pengamatan monitoring yang dilakukan di demplot sawah dengan cara praktik dengan bimbingan dan arah tim pelaksana kegiatan. Kegiatan ini dilaksanakan dengan memberikan materi berupa, pengenalan biologi hama baru ulat grayak jagung, cara pengendalian hingga panen. Kedua adalah diskusi hasil praktik lapangan yang dilakukan di rumah salah satu kelompok tani. Kegiatan pelatihan ini dihadiri oleh 30 orang yang terdiri dari anggota kelompok tani Rahayu dan petugas penyuluh lapangan dari Dinas Pertanian Kabupaten Lombok Barat, seperti dalam Gambar 2.

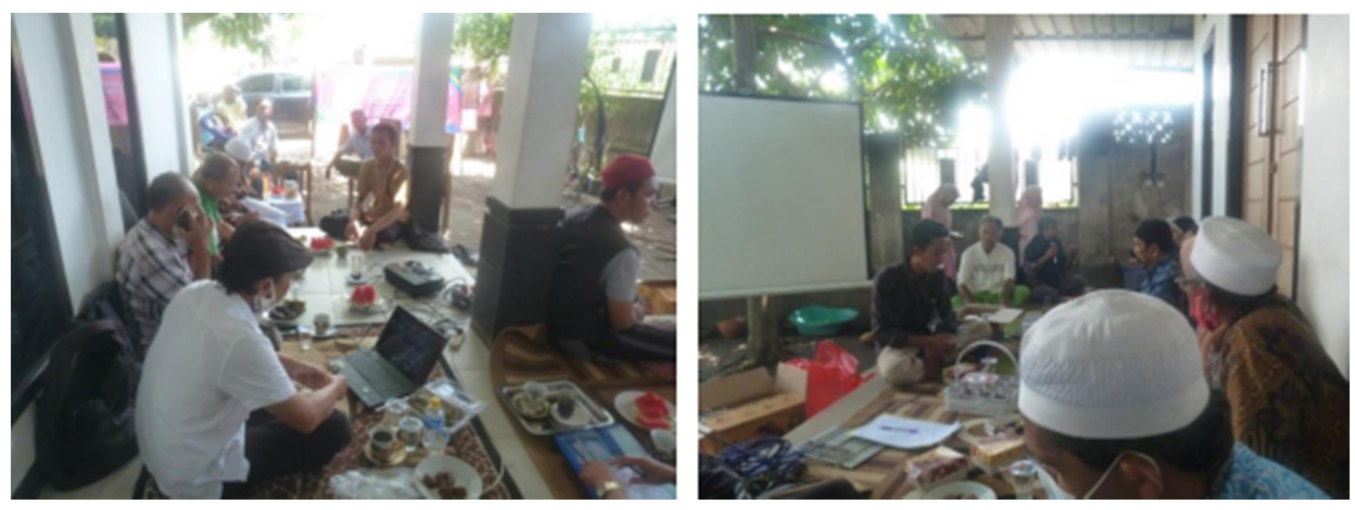

Gambar 2.

Suasana saat pelatihan dan diskusi hasil praktek lapangan Demplot

\section{Demplot Pelaksanaan Kegiatan}

Demonstrasi plot dilakukan dengan melakukan penyewaan lahan sawah milik salah satu kelompok petani Jagung yang ada di Desa Jatisela Dusun Ireng. Kegiatan ini dilibatkan pada petani dan kelompok tani jagung yang bergabung dalam Kelompok tani "Rahayu" Salah satu sawah milik anggota kelompok tani Rahayu (Bapak Zunaidi) dengan luas 10 are. Sawah tersebut diøunakan sebagai contoh untuk melakukan sistem nengendalian hama ulat 
grayak jagung. Demplot dilakukan dengan memanfaatkan tanaman refusia dan monitoring hama tanpa penggunaan pestisida. Hasil pelaksanaan Demplot tampak disajikan dalam dokumentasi Gambar 3.

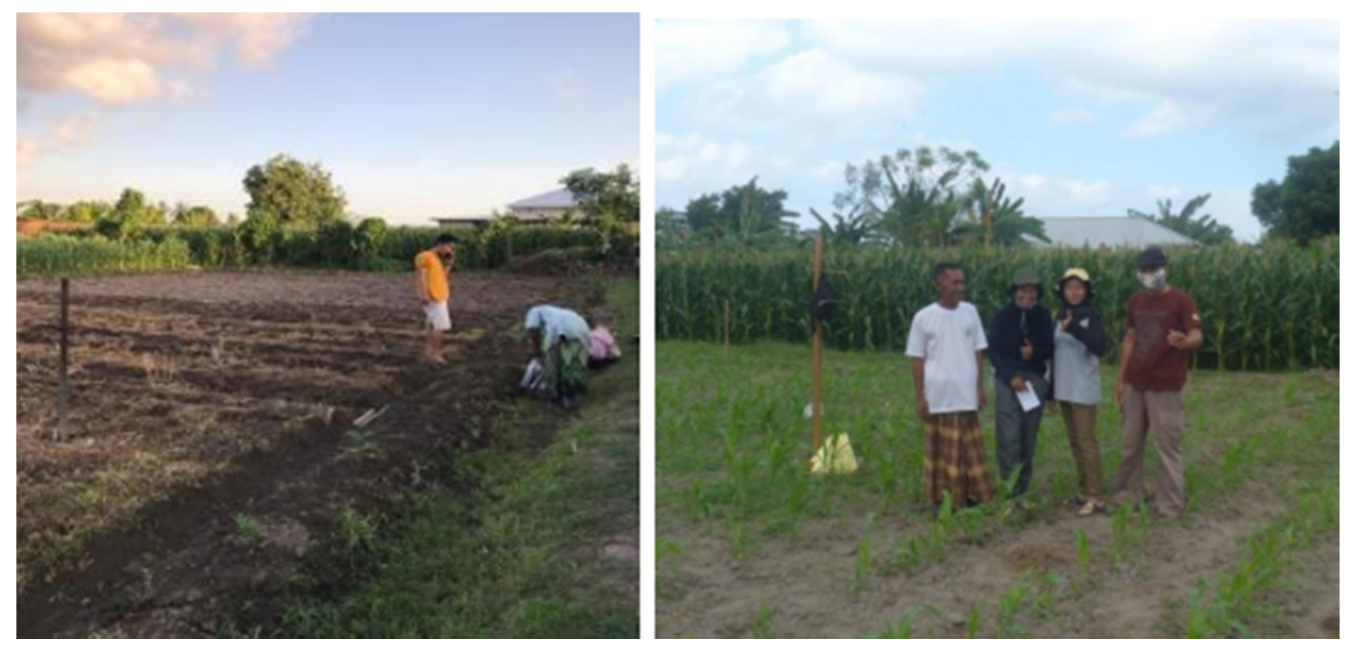

Gambar 3.

Demplot tanaman jagung dengan refusia dengan melibatkan langsung petani

Hasil praktek perkembangan hasil monitoring jumlah kelompok telur Spodoptera frugiperda pada demplot dan tempat sawah milik petani tampak sedikit berbeda, seperti tersajikan dalam Gambar 4 berikut:

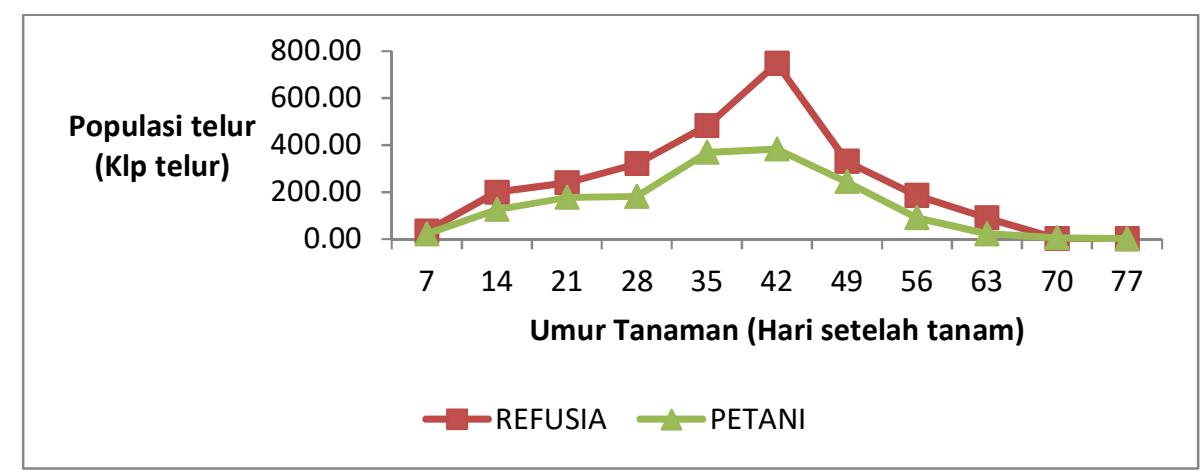

Gambar 4.

Perkembangan jumlah telur yang diletakkan sesuai dengan umur tanaman jagung di demplot dan cara petani.

Perkembangan populasi kelompok telur memiliki pola yang mirip antara pertanaman jagung milik petani dan demplot. Populasi cenderung meningkat seiring dengan bertambahnya umur tanaman jagung. Jumlah kelompok telur ditemukan mencapai puncak saat umur jagung berkisar antara 40 hari setelah tanam. Hasil monitoring kerusakan yang ditimbulkan setiap umur jagung menunjukkan bahwa hama ulat Spodoptera lebih suka menyerang tanaman masih muda daripada tanaman jagung tua. Adanya hasil ini peserta lebih memahami dan mengerti, bahwa hama baru ini menyerang tanaman muda. Kondisi tersebut memiliki kesamaan dari beberapa peneliti yang mengatakan bahwa hama ulat grayak jagung di lapangan hanya ditemukan pada saat stadium vegetative (Nurnina, 2020, Capinera 2017, Maharani et al., 2019, Robert et al., 2008) 


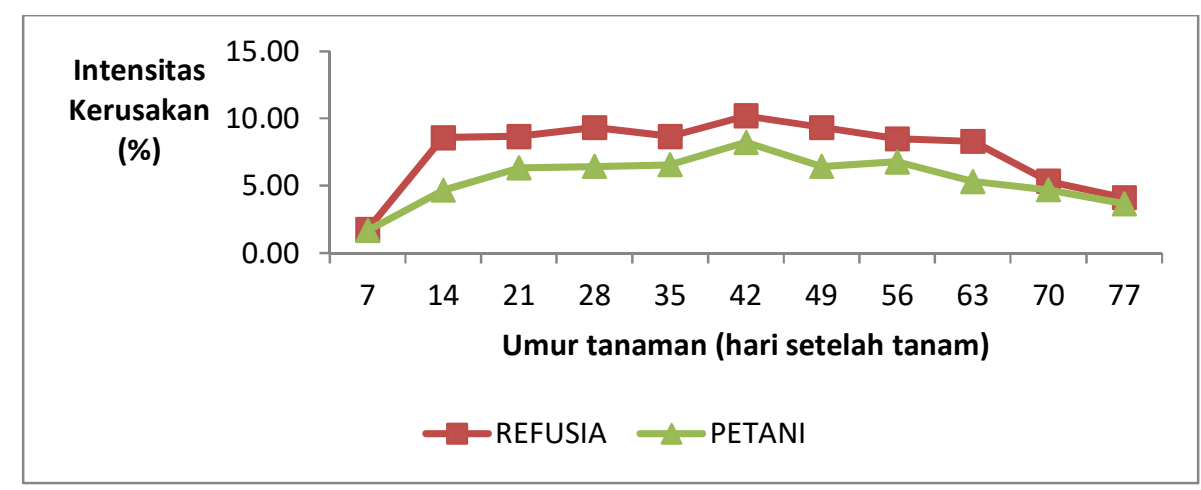

Gambar 5.

Itensitas kerusakan tanaman jagung yang disebabkan oleh Spodoptera frugiperda di demplot dan cara petani.

Gambar 4 dan 5 tampak menunjukkan bahwa populasi telur dan intensitas serangan hama ulat grayak terjadi perbedaan pada lahan demplot dibandingkan dengan lahan milik petani. Salah satu penyebab perbedaan kedua hal tersebut adalah perlakuan pestisida yang intensif yang dilakukan oleh petani. Sementara dalam demplot tidak pernah dilakukan tindakan pengendalian dengan cara kimiawai dan hanya monitoring keberadaan hama. Perbandingan hasil jagung cara petani diperoleh menunjukkan sedikit lebih rendah (688 kg/10 are) yang berbeda nyata dibandingkan dengan demplot ( $898 \mathrm{~kg} / 10$ are), demikian juga kualitas jagung pipilnya lebih bagus hasil demplot. Adanya kegiatan real praktek dengan membandingkan apa yang petani peroleh dan demplot petani semakin mengerti dan menerima teknologi yang tim introduksikan ini.

\section{KESIMPULAN DAN SARAN}

Hasil dan kesimpulan dari kegiatan pengabdian seperti berikut: (a) Petani peserta kegiatan pengabdian semakin memahami strategi teknik pengendalian hama invasi baru ulat grayak jagung untuk menggunakan tanaman refusia dan monitoring. (b) Petani semakin yakin mengerti dengan praktek langsung penerapan Demontrasi Plot teknik pengendalian tanam refusia dan monitoring dapat menekan serangan hama ulat grayak hingga $80 \%$ (c). Hasil analisis Teknik pengendalian yang dipraktikkan oleh peserta petani dengan arahan tim pengabdian menunjukkan penghematan biaya pembelian pestisida hingga 100\%. (d) Petani semakin mengerti dengan adanya perbandingan antara hasil Demplot dan cara petani, yaitu kualitas dan hasil jagung pipil demplot lebih bagus daripada teknik pengendalian cara petani setempat.

\section{Ucapan Terima Kasih}

Penulis mengucapkan terima kasih kepada LPPM Universitas Mataram yang telah memberi dukungan finansial terhadap kegiatan pengabdian ini, sesuai dengan Surat Perjanjian Nomor: 2183/UN18/LPPM/2020 tanggal, 4 Mei 2020. Ucapan terimakasih juga kami sampaikan kepada Mahasiswa serta anggota Kelompok Tani Rahayu dusun Ireng, Desa Jatisela yang terlibat dalam kegiatan ini atas segala tenaga dan waktunya. 


\section{Daftar Pustaka}

BPS Provinsi NTB, 2019. Statistik Tanaman Pangan Provinsi Nusa Tenggara Barat, Mataram. 2019.

BPTP NTB, 2019. Data Sebaran OPT Utama Tanaman Padi dan Jagung. Balai Perlindungan Tanaman Pertanian (BPTP) NTB. Narmada.

CABI. 2019. Spodoptera frugiperda (Fall Armyworm). https://www.cabi.org/ISC/ fallarmyworm. Diakses pada tanggal: 8 November 2019.

Capinera, John L,. 2017. Fall Armyworm, Spodoptera frugiperda (J.E. Smith) (Insecta: Lepidoptera: Noctuidae). IFAS Extension, Universitas of Florida.

[Kementan] Kementerian Pertanian. 2019. Pengenalan Fall Armyworm (Spodoptera frigiperda J. E. Smith) Hama Baru pada Tanaman Jagung di Indonesia. Jakarta: Balai Penelitian Tanaman Serealia. 64 p.

Maharani Y, Dewi V.K., Puspasari L.T., Rizkie L, Hidayat. Y., dan Dono D. 2019. Cases of Fall Army Worm Spodoptera frugiperda J. E. Smith (Lepidoptera: Noctuidae) Attack on Maize in Bandung, Garut and Sumedang District,West Java. Jurnal Cropsaver. 2(1): 38-46.

Nurmina N, 2020. Perkembangan dan Kerusakan Hama Ulat Grayak Jagung (Spodoptera frugiperda J. Smith) pada beberapa Lokasi Pertanaman Jagung di Indonesia. Makalah Webinar Pengelolaan Spodoptera frugiperda di Indonesia, 21 p. , Bogor 26 September 2020.

Robert L. M, Eagher, Julieta B, Rambila And Edward H, 2008. Monitoring For Exotic Spodoptera species (Lepidoptera: Noctuidae) In Florida. https://bioone.org/journals/Florida-Entomologist (diakses pada 22 Oktober 2019).

Sharanabasappa, C. M. Kalleshwaraswamy, J. Poorani, M. S. Maruthi, H. B. Pavithra, and J. Diraviam. 2019. Natural enemies of Spodoptera frugiperda (J. E. Smith) (Lepidoptera: Noctuidae), a recent invasive pest on maize in South India. Florida Entomologist. 102(2): 619-623.

Supeno B., Meidiwarman, Tarmizi, Hery Hariyanto., 2020. Eksplorasi Dan Sebaran Musuh Alami Lokal Hama Baru Ulat Gerayak Jagung (Fall Armyworm / FAW), Spodoptera frugiperda Di Pulau Lombok. Laporan Hasil Penelitian, LPPM Universitas Mataram. 35 p.

Supeno B., Tarmizi, Hery Haryanto, Ni Made Laksmi Ernawati. 2021. Parasitoid of Fall Armyworm/FAW, Spodoptera frugiperda (Lepidoptera: Noctuidae) on Mize at Lombok Island. Preocceding ICST 2: 460-466. 